\title{
Dietary determinants of circulating insulin-like growth factor (IGF)-I and IGF binding proteins $1,-2$ and -3 in women in the Netherlands
}

\author{
Alina Vrieling ${ }^{1}$, Dorien W. Voskuil ${ }^{1,2}$, H. Bas Bueno de Mesquita ${ }^{3}$, Rudolf Kaaks ${ }^{4}$, Paul A.H. van Noord ${ }^{5}$, \\ Lital Keinan-Boker ${ }^{5}$, Carla H. van Gils ${ }^{5}$ \& Petra H.M. Peeters ${ }^{5, *}$ \\ ${ }^{1}$ Division of Experimental Therapy, The Netherlands Cancer Institute, Amsterdam, The Netherlands; ${ }^{2}$ Division of \\ Psychosocial Research and Epidemiology, The Netherlands Cancer Institute, Amsterdam, The Netherlands; ${ }^{3}$ National \\ Institute of Public Health and Environment, Bilthoven, The Netherlands; ${ }^{4}$ International Agency for Research on \\ Cancer, Lyon, France; ${ }^{5}$ Julius Center for Health Sciences and Primary Care, Utrecht Medical Center, Utrecht, The \\ Netherlands
}

Received 10 November 2003; accepted in revised form 27 April 2004

Key words: diet, phytoestrogens, lycopene, insulin-like growth factor-I (IGF-I), IGF binding proteins (IGFBPs).

\begin{abstract}
Objective: Epidemiological studies suggest that individuals with elevated plasma concentrations of insulin-like growth factor (IGF-I) are at increased risk of developing cancer. We assessed whether dietary intake of total energy, protein, alcohol, phytoestrogens and related foods, and tomatoes and lycopene was associated with plasma levels of IGF-I and IGF binding proteins (IGFBPs) in Dutch women.

Methods: A cross-sectional study was conducted in 224 premenopausal and 162 postmenopausal women, aged 49-69, participating in the Prospect-EPIC study in the Netherlands. Diet was assessed using a food frequency questionnaire.

Results: In postmenopausal women, higher alcohol intake was associated with lower plasma IGFBP-1 concentrations (alcohol 1.4 to $20 \mathrm{~g} /$ day: 20\% decrease in IGFBP-1; $p=0.04$ ), and higher intake of plant lignans was associated with higher IGFBP-1 concentrations (plant lignans 0 to $1 \mathrm{mg} / \mathrm{day}: 59 \%$ increase in IGFBP-1; $p=0.02$ ). Higher soy intake was associated with higher plasma IGFBP-2 concentrations in premenopausal women (soy 0 to $2.5 \mathrm{~g} /$ day: $3 \%$ increase in IGFBP-2; $p=0.04$ ). No independent associations of dietary factors with IGF-I or IGFBP-3 concentrations were observed. However, in premenopausal women alcohol intake was inversely associated with IGF-I and positively associated with IGFBP-3 after mutual adjustment.

Conclusions: In this study population, with limited variation in dietary intake, total energy, protein, phytoestrogens and lycopene were not associated with IGF-I and IGFBP-3. Alcohol was inversely, and some measures of phytoestrogen intake were positively associated with plasma IGFBP-1 or -2 concentrations. The roles of IGFBP-1 and -2 in relation to IGF-I bioactivity and cancer deserve further investigation.
\end{abstract}

\section{Introduction}

Insulin-like growth factor I (IGF-I) is important in normal growth and development. However, it has also been shown to promote tumor growth [1]. Prospective cohort studies have observed that subjects with elevated

*Address correspondence to: P.H.M. Peeters, Julius Center for Health Sciences and Primary Care, University Medical Center, Utrecht, Room STR 6.1.31, PO Box 85060, 3508 BA Utrecht, The Netherlands. Ph.: +31 30250 9363; Fax: + 3130250 5485; E-mail: P.H.M.Peeters@umcutrecht.nl levels of IGF-I are at increased risk of developing several types of cancer, including prostate, premenopausal breast, and colorectal cancer [2-8]. IGF action is determined by the availability of IGF-I to interact with the IGF-I receptor, and is dependent not only on absolute IGF-I concentrations, but also on the relative concentrations of several IGF binding proteins IGFBPs [9]. A high concentration of IGFBP-3, the main IGF binding protein in the circulation, is thought to reduce IGF-I action. However, studies on the association between plasma IGFBP-3 levels and cancer risk remain inconclusive [2, 3, 5-8]. Only a small fraction of IGF-I in 
the circulation is bound to IGFBP-1 and IGFBP-2, in complexes which allow transport of IGF-I out of the bloodstream, possibly resulting in increased levels of IGF-I in tissues. Ultimately, at the receptor level, binding of IGF-I to any of the IGFBPs inhibits IGFaction. Serum levels of IGF-I as well as the IGFBPs vary substantially between subjects, and are determined by both genetic and environmental factors, e.g. dietary factors [10].

Previous studies investigating the regulation of the IGF-system by diet have mainly focused on total energy and protein intake. Severe energy and protein restriction was found to lower serum IGF-I levels in both animals and humans [11]. Results of cross-sectional studies investigating the relation between the normal range of energy and protein intake and serum IGF-I levels are conflicting [12-20], with only few studies showing a significant positive association [21-24]. Alcohol consumption can possibly increase IGF-I production by the liver [25], but has been inconsistently related to IGF-I and IGFBP-3 levels in cross-sectional studies [14, 15, 17, $22,26]$.

Several micronutrients or bioactive compounds in foods may also affect the IGF-system. Estrogen action is strongly interrelated with the IGF-system, and selective estrogen receptor modulators (e.g. tamoxifen, raloxifene) have been shown to lower serum IGF-I levels [27-29], and may elevate some IGFBP levels [27, 28]. Phytoestrogens are plant substances that structurally resemble endogenous estradiol and are able to bind to its receptor [30]. Therefore, we hypothesized that phytoestrogens may also potentially decrease IGF-I concentrations. Four human intervention studies investigated the effect of soy protein, an important source of phytoestrogens, on serum IGF-I, but produced conflicting results [31-33, 55]. Additionally, results differed for pre- and postmenopausal women [31], which suggests that the effects of phytoestrogens on the IGF system components may be dependent on endogenous estradiol concentrations. Lycopene is an anti-oxidant mainly found in cooked or processed tomatoes, and has been suggested to interfere with IGF signaling in experimental studies [34-36]. Also in cross-sectional studies lycopene [22] or cooked or processed tomatoes $[14,18]$ were associated with IGF-I or IGFBP-3.

The objective of the present cross-sectional study was to assess whether dietary intake of total energy, protein, alcohol, phytoestrogens and related foods, and tomatoes and lycopene, was associated with plasma levels of IGF-I or with any of its three main binding proteins (IGFBP-1, -2, and -3) in premenopausal and postmenopausal Dutch women.

\section{Materials and methods}

\section{Study population}

The study population is a sample of premenopausal and postmenopausal participants of the Prospect cohort which is part of the ongoing European Prospective Investigation into Cancer and Nutrition (EPIC) [37]. In the Prospect-EPIC study a total of 17,357 women, living in Utrecht (the Netherlands) and surroundings, were enrolled between 1993 and 1997 and are subsequently followed for the occurrence of cancer. Women were recruited among participants of the nation-wide breast cancer screening program, and 49-69 years of age. The participation rate of the Prospect-EPIC study was approximately $35 \%$ [38].

Premenopausal women did not previously undergo bilateral ovariectomy, reported at least 10 menses during the last 12 months, and did not use any hormones for contraception or (peri)menopausal complaints. The total number of women meeting these selection criteria represented $9 \%(n=1357)$ of all women in the cohort. We further excluded women with insulin-dependent diabetes mellitus $(n=7)$ or a diagnosed malignancy at baseline $(n=66)$, as these diseases may affect circulating hormone/peptide levels. Additionally, for practical reasons, we had to exclude 12 women because one or more questionnaires were missing, as well as 335 women because no plasma was available for cross-sectional analyses (i.e. all women enrolled before 1995). A resulting total of 937 eligible women was available for further study. As has been described previously [39], we over-sampled 50 women who performed regular physical activities of moderate intensity for at least $30 \mathrm{~min} / \mathrm{day}$, and 48 women who reported not performing physical activities. We randomly selected 126 women from the remaining eligible women, resulting in a selection of a total of 224 premenopausal women.

We further included 163 cancer-free postmenopausal women from a previously conducted case-control study on circulating IGF levels and risk of postmenopausal breast cancer [40]. They were matched to each breast cancer case at $2: 1$ ratio $(+10 \%)$ by age ( \pm 1 year), and date of enrollment. These women reported their last menstruation 12 months or more before time of enrollment, and were non-users of hormone-replacement therapy (HRT) and insulin. One woman was excluded because of missing data on food intake. In total, we have selected 224 premenopausal and 162 postmenopausal women as our study population. 


\section{Data collection}

Baseline information was collected using self-administered questionnaires and a standardized medical examination. The general questionnaire consisted of questions on demographic characteristics, presence of chronic diseases of interest, and potential risk factors for cancer, i.e. reproductive history, family history, drinking of alcohol, smoking habits, and physical activity. The total physical activity score is a summary measure, combining household, occupational and recreational physical activity [41]. Missing values for physical activity score were imputed by the mean value of pre- or postmenopausal women $(n=27)$.

The self-administered food frequency questionnaire (FFQ) referred to habitual intake of 178 food items during the preceding year [42, 43]. The questionnaire contained color photographs of 2-4 different-sized portions of 21 food items, which helped assessing the serving size. Subjects indicated their consumption frequency of each food item on a daily/weekly/monthly/ yearly scale or as never consumed. An adapted version of the 1993 computerized Dutch food composition table was used to calculate energy and nutrient intake. To calculate lycopene intake, an adapted version of the 2001 computerized Dutch food composition table was used. Phytoestrogen intake was calculated using published laboratory analysis data for the phytoestrogen contents of relevant food items [44, 45]. Total phytoestrogens is calculated as the sum of total isoflavones (daidzein, genistein, formononetin, biochanin A) and plant lignans (matairesinol, secoisolariciresinol).

The physical examination included measurements of blood pressure and anthropometric indices (i.e. height, weight, waist and hip circumferences), as well as the collection of a $30 \mathrm{ml}$ blood sample. The blood collection protocol included recording of time since last consumption of food or drinks (median: $2 \mathrm{~h}$, range $2 \mathrm{~min}-13 \mathrm{~h}$ ). Hemolysis of the blood samples has been recorded and samples were excluded if any severe hemolysis had occurred. All blood samples were drawn and processed by qualified research assistants and stored in liquid nitrogen $\left(-196^{\circ} \mathrm{C}\right)$ in $500 \mu$ l plastic straws, until transportation on dry-ice to Lyon, France.

\section{$I G F-I, I G F B P-1, I G F B P-2$, and IGFBP-3 assays}

Plasma concentrations of IGF-I, IGFBP-1, IGFBP-2, and IGFBP-3 were analyzed in the Hormones and Cancer Laboratory at the International Agency for Research on Cancer, Lyon, France, using immunoassays from Diagnostic Systems Laboratories (Webster, Texas, USA). For measurement of IGFBP-2 a compet- itive radioimmunoassay was used. IGF-I, IGFBP-1, and IGFBP-3 were measured by double-antibody immunoradiometric assays. The IGF-I assay was preceded by an acid-ethanol precipitation procedure to extract IGF-I from its binding proteins. Control samples were included in each batch to calculate inter-assay coefficients of variation $(\mathrm{CV})$. The detection limit varied between 0.01 and $0.80 \mathrm{ng} / \mathrm{ml}$ for these assays. In one sample a IGFBP-1 concentration below the detection limit was found, and this value was excluded from statistical analyses. Samples for postmenopausal women were analysed a year after those for premenopausal women. The intra- and inter-assay CVs ranged between $1.1 \%$ and $8.5 \%$, and between $4.7 \%$ and $17.0 \%$, respectively $[39,40]$.

\section{Data analysis}

The following dietary factors were investigated: total energy, protein (total, animal, plant), alcohol, phytoestrogens (total phytoestrogens, total isoflavones, plant lignans) and related foods (soy, legumes, cereals), tomatoes (raw and processed), and lycopene. Food groups consisted of the following items: soy products (tempeh, tofu, vegetarian burgers); cereals (pasta, rice, other grains, bread, crispbread, rusks, breakfast cereals, crisps and salty biscuits, dough and pastry); processed tomatoes (cooked tomatoes, concentrated tomato paste, tomato sauce). Total, animal, and plant protein were adjusted for total energy intake using the residual analysis method [46]. All analyses were conducted for pre- and postmenopausal women separately, because these two groups were selected separately, and blood analyses for both groups were performed with a 1 year interval. In addition, due to the known interaction between estrogens and IGF, the relation between dietary factors and the IGF-system might be different for preand postmenopausal women.

Pearson correlation coefficients were calculated to assess the association between plasma levels of IGF-I, IGFBP-1, IGFBP-2, and IGFBP-3 and dietary factors. Pre- and postmenopausal women were categorized separately, based on tertiles or relevant categories of dietary factors, and mean concentrations of IGF-I, IGFBP-1, IGFBP-2, and IGFBP-3 were calculated in each category of dietary factors. Tertiles were used for total energy, protein, cereals, and lycopene. For alcohol, soy, legumes, and tomatoes, relevant categories were used: for alcohol < 1 glass/week (1.43 g/day), 1 glass/ week $-<2$ glasses/day ( $20 \mathrm{~g} /$ day), and $\geq 2$ glasses/day; for soy $0,>0-<2.5$ (= median intake of soy consumers), and $\geq 2.5 \mathrm{~g} /$ day; for legumes $<1$ (7 g/day), $1-<2$ (14 g/day), and $\geq 2$ serving sizes/week; for raw tomatoes 
$<0.5$ ( $5 \mathrm{~g} /$ day $), 0.5-<1$ ( $10 \mathrm{~g} /$ day $),$ and $\geq 1$ tomatoes/ week; and for processed tomatoes $<2(7 \mathrm{~g} /$ day $), 2-<4$ (14 g/day), and $\geq 4$ sauce spoons/week.

Multivariate linear regression models were constructed to quantify the association between plasma levels of IGF-I, IGFBP-1, IGFBP-2, and IGFBP-3 (as continuous dependent variables in separate models) and dietary factors (as continuous independent variables). Data on IGFBP-1 concentrations were $\ln$ (concentration +1 )-transformed, to normalize the distribution of this variable. All linear models have been adjusted for age, BMI, physical activity score, time since last meal or drink, and total energy intake. Since IGF-I and IGFBP3 are known to be strongly co-regulated, models for IGF-I plasma levels were also adjusted for IGFBP-3 plasma levels, and vice versa. As the regression coefficients and the mean plasma concentrations in dietary categories led to similar conclusions, we have chosen to present only the results of the regression analyses.

The regression coefficients obtained from the regression models were expressed as changes per serving increment $(\Delta s)$. The serving increments used were defined as the difference between the tertile or category cut-off points (as described above), for pre- and postmenopausal women separately. Due to very low intakes and limited variation in intakes of total phytoestrogens, total isoflavones, and plant lignans, a serving increment of $1 \mathrm{mg}$ /day was used. P-values below 0.05 were considered to be statistically significant. The SPSS version 10.0 package was used for statistical analyses.

\section{Results}

Basic characteristics of our study population are described in Table 1. IGF-I, IGFBP-1, IGFBP-2, and IGFBP-3 concentrations were within the normal range. IGF-I concentrations were slightly higher for premenopausal than for postmenopausal women. As described in our previous studies, plasma concentration of IGF-I was strongly positively correlated to the concentration of IGFBP-3 (Pearson correlation coefficient $(r)=0.58$ and $r=0.60 ; p<0.001)[39,40]$. Similarly, plasma concentrations of IGFBP-1 and IGFBP-2 were positively correlated $(r=0.37$ and $r=0.30 ; p=0.01)[39,40]$. Dietary intakes of phytoestrogens and related foods, and lycopene and tomatoes were relatively low.

Pearson correlation coefficients between dietary factors and plasma IGF-I, IGFBP-1, IGFBP-2 and IGFBP-3 ranged from -0.14 to 0.20 , and -0.13 to 0.18 for pre- and postmenopausal women, respectively (data not shown). Statistically significant correlations were observed for raw tomatoes and IGFBP-1 $(r=0.16$; $p=0.02)$, animal protein and IGFBP-2 $(r=-0.14$; $p=0.04)$, and soy products and IGFBP-2 $(r=0.20$; $p=0.002$ ) in premenopausal women. For postmenopausal women, only plant lignans were statistically significantly correlated with IGFBP-1 $\quad(r=0.18$; $p=0.02$ ).

Tables 2-4 present the results of the multivariate linear regression analyses. No significant associations between plasma IGF-I and IGFBPs, and total energy and protein (total, animal, plant) intake in both pre- and postmenopausal women were observed (Table 2). Alcohol intake was inversely associated with plasma IGF-I and positively associated with plasma IGFBP-3 in premenopausal women. For example, an increase in alcohol intake of $18.6 \mathrm{~g} /$ day (moving from the lowest tertile cut-off point $(1$ glass $/$ week $=1.4 \mathrm{~g} /$ day $)$ to the highest tertile cut-off point ( 2 glasses/day $=20 \mathrm{~g} /$ day), is associated with a $6 \%$ decrease in IGF-I $(-9.4 \mathrm{ng} / \mathrm{ml}$; $p=0.04)$ and a $3 \%$ increase in IGFBP-3 $(90.7 \mathrm{ng} / \mathrm{ml}$; $p=0.02$ ). In postmenopausal women, increased alcohol intake was associated with a $20 \%$ decrease in plasma IGFBP-1 concentrations $(-2.8 \mathrm{ng} / \mathrm{ml} ; p=0.04)$.

Of the phytoestrogens and related foods (Table 3), increased soy intake was associated with increased plasma IGFBP-2 concentrations in premenopausal women $(10.6 \mathrm{ng} / \mathrm{ml}(3 \%)$ increase in IGFBP-2 with each $2.5 \mathrm{~g} /$ day increase in soy intake; $p=0.04)$. In postmenopausal women, intake of plant lignans was positively associated with plasma IGFBP-1 concentrations (example: increase of $5.8 \mathrm{ng} / \mathrm{ml}(59 \%)$ in IGFBP-1 with an increase in plant lignans intake from 0 to $1 \mathrm{mg}$ / day, $p=0.02$ ). No statistically significant associations were observed for phytoestrogens or related foods and IGF-I or IGFBP-3 concentrations.

For intake of lycopene and tomatoes, no statistically significant associations were found with plasma components of the IGF-system (Table 4).

\section{Discussion}

In our population of Dutch pre- and postmenopausal women, no statistically significant associations were found between energy and protein intake and IGF-I, IGFBP-1, IGFBP-2, and IGFBP-3 plasma concentrations. Similarly, within the relatively low intakes of phytoestrogens and lycopene in our population, no significant associations of these compounds with plasma concentrations of IGF-I and IGFBP-3 were observed. However, intakes of some (sources of) phytoestrogens were significantly positively associated with IGFBP-1 or -2 . Furthermore, higher alcohol intake was significantly associated with lower IGF-I and higher IGFBP-3 
Table 1. Selected characteristics of pre- and postmenopausal women, Prospect-EPIC, 1993-1997

\begin{tabular}{|c|c|c|}
\hline Variable (unit) & $\begin{array}{l}\text { Premenopausal }(\mathrm{n}=224) \\
\text { Median (interquartile range }^{\mathrm{a}} \text { ) }\end{array}$ & $\begin{array}{l}\text { Postmenopausal }(\mathrm{n}=162) \\
\text { Median (interquartile range }^{\mathrm{a}} \text { ) }\end{array}$ \\
\hline \multicolumn{3}{|l|}{ General characteristics } \\
\hline Age (years) & $50(49-51)$ & $60(55-65)$ \\
\hline Height (cm) & $165(161-169)$ & $164(160-168)$ \\
\hline Weight (kg) & $67(60-77)$ & $68(63-77)$ \\
\hline Body mass index $\left(\mathrm{kg} / \mathrm{m}^{2}\right)$ & $25(22-27)$ & $26(23-29)$ \\
\hline \multicolumn{3}{|l|}{ Macronutrients } \\
\hline Total energy (kJ/day) & $7654(6330-8909)$ & $7556(6527-8924)$ \\
\hline Total protein (g/day) & $70.5(59.9-84.1)$ & $73.0(62.0-86.2)$ \\
\hline Animal protein (g/day) & $46.0(36.9-55.8)$ & $47.9(38.9-58.6)$ \\
\hline Plant protein (g/day) & $24.3(20.4-28.5)$ & $24.4(20.2-29.1)$ \\
\hline Alcohol (g/day) & $8.5(1.8-20.0)$ & $2.8(0.2-12.4)$ \\
\hline \multicolumn{3}{|l|}{ Food groups } \\
\hline Soy products (g/day) & $0.0(0.0-1.9)$ & $0.0(0.0-1.4)$ \\
\hline Legumes (g/day) & $7.0(3.2-13.6)$ & $8.3(3.8-13.9)$ \\
\hline Cereals (g/day) & $162(121-208)$ & $143(113-187)$ \\
\hline Tomatoes, raw (g/day) & $5.7(2.8-10.5)$ & $3.7(1.6-7.4)$ \\
\hline Tomatoes, processed (g/day) & $10.3(4.4-18.6)$ & $5.2(1.0-13.2)$ \\
\hline \multicolumn{3}{|l|}{ Micronutrients } \\
\hline Total phytoestrogens (mg/day) & $0.86(0.48-1.12)$ & $0.77(0.42-1.06)$ \\
\hline Total isoflavones (mg/day) & $0.15(0.09-0.24)$ & $0.14(0.09-0.23)$ \\
\hline Plant lignans (mg/day) & $0.63(0.30-0.87)$ & $0.54(0.25-0.86)$ \\
\hline Lycopene (mg/day) & $3.02(1.81-4.45)$ & $2.17(1.10-3.71)$ \\
\hline \multicolumn{3}{|l|}{ IGF plasma concentrations } \\
\hline IGF-l (ng/ml) & $150.3(116.7-184.5)$ & $148.3(112.6-175.0)$ \\
\hline IGFBP-1 (ng/ml) & $14.5(7.8-29.6)$ & $11.6(7.4-22.9)$ \\
\hline IGFBP-2 (ng/ml) & $400.0(259.3-574.3)$ & $394.8(281.6-562.9)$ \\
\hline IGFBP-3 (ng/ml) & $3057.7(2718.8-3393.2)$ & 3155.7 (2861.9-3599.9) \\
\hline
\end{tabular}

\footnotetext{
${ }^{\mathrm{a}}$ Interquartile range (p25-p75).
}

plasma concentrations in premenopausal women, and with lower plasma IGFBP-1 concentrations in postmenopausal women. As we studied several dietary factors in relation to four IGF-system components, we cannot exclude that some of our findings may be due to chance.

Elevated serum IGF-I concentrations have been associated with increased cancer risk [2-8], however, the association of IGFBP-3 concentrations with cancer risk remains controversial. Some studies have shown an increase in risk for higher IGFBP-3 concentrations $[3,5,8]$, others have observed a decrease in risk $[2,6,7]$. In epidemiological studies, the IGF-I/IGFBP-3 molar ratio has been used as an approximate index of 'free', bioactive IGF-I, since IGFBP-3 is the main binding protein of IGF-I in the circulation. However, the biological effects of the different IGF binding proteins on IGF-I bioactivity are still relatively unknown. Similar to IGFBP3 , IGFBP-1 and -2 may also reduce bioactive IGF-I by binding to it and making it unavailable for the IGF-I receptor. On the other hand, IGFBP-1 and -2 allow the transport of IGF-I out of the bloodstream, which may result in increased IGF-I concentrations at the tissue level.
Since it is unknown which is the relevant measure of bioactive IGF-I, we did not use a proxy such as the IGF-I/ IGFBP-3 molar ratio.

Energy balance, dietary energy intake, and to a lesser extent protein intake, may be linked to cancer risk [47, 48] and have been implicated in the modulation of the IGF-system. Experimental studies in animals and humans have shown that severe dietary energy and protein restriction (e.g. fasting) results in an acute decrease in IGF-I, acute increase in IGFBP-1, chronic increase in IGFBP-2, and chronic decrease in IGFBP-3 [11]. Both energy and protein are needed to restore IGF-I after fasting [11]. Our results, in a study population with adequate intake of energy and protein, are consistent with most previous cross-sectional studies, in which no association between energy and protein intake and circulating IGF-I and IGFBP-3 was observed [12-20]. The two largest cross-sectional studies did show a positive association between IGF-I and protein intake within the normal range [22, 23], as is also found by two smaller studies [21, 24]. However, with respect to protein intake and IGFBP-3 concentrations, and energy intake 
Table 2. Changes $(\Delta)$ in plasma IGF-I, IGFBP-1, IGFBP-2, and IGFBP-3 $(\mathrm{ng} / \mathrm{ml})$ for a specified increment of macronutrient intake in 224 premenopausal and 162 postmenopausal women, separately ${ }^{\mathrm{a}}$

\begin{tabular}{|c|c|c|c|c|c|c|c|c|c|}
\hline \multirow[t]{2}{*}{ Dietary factors } & \multirow[t]{2}{*}{ Serving increment ${ }^{b}$} & \multicolumn{2}{|l|}{ IGF-I ${ }^{\mathrm{c}}$} & \multicolumn{2}{|l|}{ IGFBP $-1^{\mathrm{d}}$} & \multicolumn{2}{|l|}{ IGFBP-2 } & \multicolumn{2}{|l|}{ IGFBP-3 ${ }^{\mathrm{c}}$} \\
\hline & & $\Delta(\mathrm{ng} / \mathrm{ml})$ & $p^{\mathrm{e}}$ & $\Delta(\mathrm{ng} / \mathrm{ml})$ & $p^{\mathrm{e}}$ & $\Delta(\mathrm{ng} / \mathrm{ml})$ & $p^{\mathrm{e}}$ & $\Delta(\mathrm{ng} / \mathrm{ml})$ & $p^{\mathrm{e}}$ \\
\hline \multicolumn{10}{|c|}{ Premenopausal women } \\
\hline Energy & $1735 \mathrm{~kJ} /$ day & 1.6 & 0.54 & -0.8 & 0.24 & -6.1 & 0.59 & 12.6 & 0.57 \\
\hline Total protein ${ }^{\mathrm{f}}$ & $5.9 \mathrm{~g} /$ day & 0.1 & 0.96 & 0.9 & 0.17 & -5.6 & 0.52 & 9.3 & 0.58 \\
\hline Animal protein ${ }^{\mathrm{f}}$ & $8.1 \mathrm{~g} / \mathrm{day}$ & 1.5 & 0.52 & 0.8 & 0.20 & -8.0 & 0.45 & 27.5 & 0.17 \\
\hline Plant protein ${ }^{\mathrm{f}}$ & $3.4 \mathrm{~g} /$ day & 3.2 & 0.14 & -0.1 & 0.87 & 4.0 & 0.67 & -35.3 & 0.05 \\
\hline Alcohol & $18.6 \mathrm{~g} /$ day & -9.4 & 0.04 & 0.2 & 0.86 & -27.3 & 0.18 & 90.7 & 0.02 \\
\hline \multicolumn{10}{|c|}{ Postmenopausal women } \\
\hline Energy & $1586 \mathrm{~kJ} /$ day & -1.9 & 0.51 & 0.04 & 0.96 & 6.7 & 0.59 & 0.4 & 0.99 \\
\hline Total protein ${ }^{\mathrm{f}}$ & $8.7 \mathrm{~g} /$ day & 3.2 & 0.24 & 1.1 & 0.09 & -9.0 & 0.45 & -7.6 & 0.78 \\
\hline Animal protein ${ }^{\mathrm{f}}$ & $8.8 \mathrm{~g} /$ day & 2.0 & 0.43 & 0.7 & 0.28 & -14.3 & 0.19 & 1.3 & 0.96 \\
\hline Plant protein ${ }^{\mathrm{f}}$ & $4.0 \mathrm{~g} /$ day & 1.9 & 0.50 & 0.8 & 0.26 & 18.4 & 0.13 & -20.6 & 0.46 \\
\hline Alcohol & $18.6 \mathrm{~g} /$ day & -10.0 & 0.08 & -2.8 & 0.04 & -16.2 & 0.52 & 111.0 & 0.06 \\
\hline
\end{tabular}

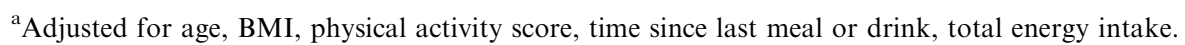

bIncrements are calculated as the difference between the extreme cut points of tertiles or relevant categories. The number of pre- and postmenopausal women in the lowest, intermediate, and highest category, respectively were for alcohol (pre: 51, 117, 56; post: 67, 45, 20).

${ }^{\mathrm{c}}$ IGF-I and IGFBP-3 are mutually adjusted for each other.

${ }^{\mathrm{d}}$ The concentrations of IGFBP-1 have been $\ln$-transformed $(\ln (1+$ conc $))$ and back-transformed values are reported.

${ }^{\mathrm{e}}$ Change in plasma levels $(\mathrm{ng} / \mathrm{ml}), p$-value.

${ }^{\mathrm{f}}$ Residual + total energy intake in linear regression model.

$R^{2}$ of the full models ranged from $34 \%$ to $43 \%$ for IGF-I, $19 \%$ to $20 \%$ for IGFBP-1, $17 \%$ to $18 \%$ for IGFBP-2, and $36 \%$ to $40 \%$ for IGFBP-3.

and IGF-I and IGFBP-3 concentrations the two largest studies are also inconsistent [22, 23]. Taken together, these results suggest that although major changes in energy and protein intake do modulate the IGF-system, the relatively minor differences observed in the general population probably do not play an important role.

Alcohol consumption has been associated with increased risk of various types of cancer [49]. For instance, risk of breast cancer is increased by moderate consumption of alcohol [50,51], but not further increased by heavy drinking (i.e., at least $60 \mathrm{~g} /$ day of alcohol) [51]. A possible biological mechanism for this association could be that moderate alcohol consumption increases IGF-I production by the liver, which is not further increased in heavy drinkers due to alcohol-induced liver damage [25]. In our study, however, higher alcohol intake was associated with decreased IGF-I and increased IGFBP-3 plasma concentrations in premenopausal women. We observed these associations only when IGF-I and IGFBP-3 were mutually adjusted for each other, suggesting departure from the usual concurrent hepatic IGF-I and IGFBP-3 stimulus. We also found that higher alcohol intake was associated with decreased IGFBP-1 concentrations in postmenopausal women. Cross-sectional studies on the association between alcohol intake and the IGF-system published to date have not investigated IGFBP-1, and have been very inconsistent with respect to IGF-I and IGFBP-3 [14, 15,
$17,22,26]$. This may be partly explained by the different ranges of intakes studied. The relevance of our findings remains unclear and needs further investigation.

Our assessment of alcohol, total energy, and protein intake has previously been shown to be reproducible [43]. However, the FFQ we used has been shown to underestimate total energy and protein intake as compared to basal metabolic rate and urinary nitrogen excretion used as reference methods, respectively. The underestimation of protein intake by the FFQ was more pronounced for relatively higher intakes. This might have led to an underestimation of a possible association between protein intake and circulating IGF system components. However, this is not thought to have markedly influenced our results, since protein intake in our study population is relatively low.

Besides energy and macronutrient intake, micronutrients or other bioactive compounds in the diet may also influence the IGF-system. Phytoestrogens are plant substances that structurally resemble endogenous estradiol and are thought to interact with the estrogen receptor. Selective estrogen receptor modulators (e.g. tamoxifen, raloxifene) have been shown to decrease circulating IGF-I levels in previous human studies [27-29], and may also increase some IGFBP levels $[27,28]$. Additionally, studies in mouse models showed a reduction of serum IGF-I or IGF-I mRNA expression in breast or prostate tissue by phytoestrogens [52-54]. 
Table 3. Changes $(\Delta)$ in plasma IGF-I, IGFBP-1, IGFBP-2, and IGFBP-3 $(\mathrm{ng} / \mathrm{ml})$ for a specified increment of phytoestrogen related foods and micronutrients intake in 224 premenopausal and 162 postmenopausal women, separately ${ }^{\mathrm{a}}$

\begin{tabular}{|c|c|c|c|c|c|c|c|c|c|}
\hline \multirow[t]{2}{*}{ Dietary factors } & \multirow[t]{2}{*}{ Serving increment ${ }^{\mathrm{b}}$} & \multicolumn{2}{|l|}{${\mathrm{IGF}-\mathrm{I}^{\mathrm{c}}}^{\mathrm{s}}$} & \multicolumn{2}{|l|}{ IGFBP-1 ${ }^{\mathrm{d}}$} & \multicolumn{2}{|l|}{ IGFBP-2 } & \multicolumn{2}{|l|}{ IGFBP-3 ${ }^{\mathrm{c}}$} \\
\hline & & $\Delta(\mathrm{ng} / \mathrm{ml})$ & $p^{\mathrm{e}}$ & $\Delta(\mathrm{ng} / \mathrm{ml})$ & $p^{\mathrm{e}}$ & $\Delta(\mathrm{ng} / \mathrm{ml})$ & $p^{\mathrm{e}}$ & $\Delta(\mathrm{ng} / \mathrm{ml})$ & $p^{\mathrm{e}}$ \\
\hline \multicolumn{10}{|l|}{ Premenopausal women } \\
\hline Soy products & $2.5 \mathrm{~g} /$ day & -0.1 & 0.95 & 0.01 & 0.98 & 10.6 & 0.04 & -12.5 & 0.19 \\
\hline Legumes & $7 \mathrm{~g} /$ day & -1.5 & 0.52 & 0.1 & 0.93 & 7.0 & 0.50 & -9.2 & 0.64 \\
\hline Cereals & 57 g/day & 3.6 & 0.26 & -1.7 & 0.05 & -16.2 & 0.26 & -9.1 & 0.74 \\
\hline Total phytoestrogens & $1 \mathrm{mg} /$ day & -0.5 & 0.75 & -0.3 & 0.42 & 9.4 & 0.17 & -0.4 & 0.98 \\
\hline Total isoflavones & $1 \mathrm{mg} /$ day & -0.3 & 0.85 & -0.3 & 0.46 & 9.2 & 0.20 & -3.4 & 0.80 \\
\hline Plant lignans & $1 \mathrm{mg} /$ day & -8.4 & 0.38 & -1.5 & 0.56 & 14.6 & 0.42 & 105.6 & 0.19 \\
\hline \multicolumn{10}{|l|}{ Postmenopausal women } \\
\hline Soy products & $2.5 \mathrm{~g} / \mathrm{day}$ & -0.1 & 0.96 & -0.2 & 0.53 & 10.8 & 0.07 & -8.1 & 0.56 \\
\hline Legumes & $7 \mathrm{~g} /$ day & 1.9 & 0.37 & 0.1 & 0.92 & 0.1 & 0.99 & -20.1 & 0.34 \\
\hline Cereals & $45 \mathrm{~g} /$ day & 3.1 & 0.33 & 1.2 & 0.14 & 7.3 & 0.60 & -3.3 & 0.92 \\
\hline Total phytoestrogens & $1 \mathrm{mg} /$ day & 0.6 & 0.80 & -0.1 & 0.80 & 6.6 & 0.53 & 3.1 & 0.90 \\
\hline Total isoflavones & $1 \mathrm{mg} /$ day & 0.5 & 0.85 & -0.5 & 0.41 & 5.8 & 0.59 & 0.8 & 0.98 \\
\hline Plant lignans & $1 \mathrm{mg} /$ day & 2.9 & 0.79 & 5.8 & 0.02 & 24.7 & 0.59 & 45.9 & 0.66 \\
\hline
\end{tabular}

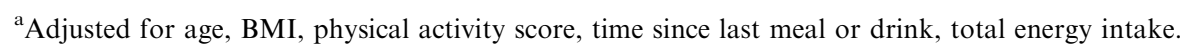

${ }^{\mathrm{b}}$ Increments are calculated as the difference between the extreme cut points of tertiles or relevant categories. The number of pre- and postmenopausal women in the lowest, intermediate, and highest category, respectively were for soy (pre: $127,55,42 ;$ post: 105, 31, 26), and for legumes (pre: $111,60,53$; post: $72,50,40$ ).

${ }^{c}$ IGF-I and IGFBP-3 are mutually adjusted for each other.

${ }^{\mathrm{d}}$ The concentrations of IGFBP-1 have been $\ln$-transformed $(\ln (1+$ conc $))$ and back-transformed values are reported.

${ }^{\mathrm{e}}$ Change in plasma levels $(\mathrm{ng} / \mathrm{ml}), p$-value.

$R^{2}$ of the full models ranged from $34 \%$ to $42 \%$ for IGF-I, $19 \%$ to $20 \%$ for IGFBP-1, $17 \%$ to $19 \%$ for IGFBP-2, and $36 \%$ to $39 \%$ for IGFBP-3.

In our cross-sectional study, with limited variation in intake of phytoestrogens and related foods, no association with IGF-I and IGFBP-3 was observed. Two recent cross-sectional studies in an Asian population with high variation in intake also did not observe any association in women [19, 20], but found a positive association between soy intake and circulating IGF-I in men [20]. Interestingly, we did find that a higher soy consumption was associated with increased plasma IGFBP-2 concentrations, and a higher intake of plant lignans with increased IGFBP-1 concentrations. This could be in line with the increased IGFBP-1 and -2 concentrations observed in vegan women, who usually have a relatively high consumption of phytoestrogens, as compared to vegetarians and meat eaters [17]. Four human intervention studies investigated the effect of soy protein intake with high isoflavones compared to soy or milk protein with low or no isoflavones, on serum IGF-I $[31-33,55]$. The results from these studies were inconsistent, and may point to opposing effects of soy protein and phytoestrogens, with IGF-I being increased by soy protein, but decreased by isoflavones. Additionally, this association may be well modified by endogenous estrogen levels, resulting in different associations for men and women, and for pre- and postmenopausal women.

Another component of the diet which may be related to the IGF-system is lycopene, an anti-oxidant mainly found in tomatoes. Tomato and lycopene intake have been associated with decreased risk of several types of cancer and possibly the IGF-system is the intermediate in this association [56]. In our study, no association between either tomatoes or lycopene and IGF-I or IGFBP-3 was observed. Four cross-sectional studies have investigated the relationship between tomato consumption $[14,15,18]$ or lycopene intake [22] and IGF-I and IGFBP-3. In three of these studies, higher intake of cooked or processed tomatoes or lycopene was associated with either lower IGF-I levels [14], higher IGFBP-3 levels [22], or a lower IGF-I/IGFBP-3 molar ratio [18]. Two in vitro studies have shown that lycopene can inhibit IGF-I-stimulated growth of endometrium and mammary cancer cell lines [34, 35]. In these studies, lycopene reduced IGF-I receptor signaling, and increased levels of membrane-associated IGFBPs [35]. Lycopene supplementation also increased plasma IGFBP-3 concentrations in ferrets [36]. In a small human intervention study, IGF-I was decreased both in the lycopene intervention as in the control group [57]. Overall, these studies suggest that lycopene might influence the IGF-system both by decreasing IGF-I and increasing IGFBPs.

We hypothesized that high intakes of phytoestrogens, lycopene, and related foods were associated with decreased IGF-I and increased IGFBP-3 concentrations, 
Table 4. Changes $(\Delta)$ in plasma IGF-I, IGFBP-1, IGFBP-2, and IGFBP-3 $(\mathrm{ng} / \mathrm{ml})$ for a specified increment of raw tomatoes, cooked tomatoes, and lycopene intake in 224 premenopausal and 162 postmenopausal women, separately ${ }^{\mathrm{a}}$

\begin{tabular}{|c|c|c|c|c|c|c|c|c|c|}
\hline \multirow[t]{2}{*}{ Dietary factors } & \multirow[t]{2}{*}{ Serving increment ${ }^{\mathrm{b}}$} & \multicolumn{2}{|l|}{ IGF-I $^{\mathrm{c}}$} & \multicolumn{2}{|l|}{ IGFBP-1 ${ }^{\mathrm{d}}$} & \multicolumn{2}{|l|}{ IGFBP-2 } & \multicolumn{2}{|l|}{ IGFBP-3 ${ }^{\mathrm{c}}$} \\
\hline & & $\Delta(\mathrm{ng} / \mathrm{ml})$ & $p^{\mathrm{e}}$ & $\Delta(\mathrm{ng} / \mathrm{ml})$ & $p^{\mathrm{e}}$ & $\Delta(\mathrm{ng} / \mathrm{ml})$ & $p^{\mathrm{e}}$ & $\Delta(\mathrm{ng} / \mathrm{ml})$ & $p^{\mathrm{e}}$ \\
\hline \multicolumn{10}{|l|}{ Premenopausal women } \\
\hline Raw tomatoes & $5 \mathrm{~g} /$ day & -3.8 & 0.09 & 1.1 & 0.09 & -3.6 & 0.72 & 21.6 & 0.25 \\
\hline Processed tomatoes & $7 \mathrm{~g} /$ day & 1.4 & 0.55 & -0.3 & 0.63 & -12.5 & 0.21 & -7.6 & 0.69 \\
\hline Lycopene & $1.86 \mathrm{mg} / \mathrm{day}$ & 0.3 & 0.90 & 0.5 & 0.53 & -11.9 & 0.33 & -16.6 & 0.47 \\
\hline \multicolumn{10}{|l|}{ Postmenopausal women } \\
\hline Raw tomatoes & $5 \mathrm{~g} /$ day & 2.7 & 0.34 & -0.1 & 0.91 & -2.8 & 0.82 & -30.3 & 0.28 \\
\hline Processed tomatoes & $7 \mathrm{~g} /$ day & -0.7 & 0.80 & -0.4 & 0.54 & -20.4 & 0.11 & 23.8 & 0.41 \\
\hline Lycopene & $1.65 \mathrm{mg} /$ day & 0.3 & 0.89 & -0.4 & 0.46 & -10.4 & 0.31 & 7.0 & 0.77 \\
\hline
\end{tabular}

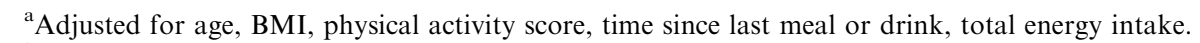

${ }^{\mathrm{b}}$ Increments are calculated as the difference between the extreme cut points of tertiles or relevant categories. The number of pre- and postmenopausal women in the lowest, intermediate, and highest category, respectively were for raw tomatoes (pre: 99, 64, 61; post: 102, 28, 32); and for processed tomatoes (pre: $80,61,83$; post: $93,34,35$ ).

${ }^{\mathrm{c}}$ IGF-I and IGFBP-3 are mutually adjusted for each other.

${ }^{\mathrm{d}}$ The concentrations of IGFBP-1 have been $\ln$-transformed $(\ln (1+$ conc $))$ and back-transformed values are reported.

${ }^{\mathrm{e}}$ Change in plasma levels $(\mathrm{ng} / \mathrm{ml}), p$-value.

$R^{2}$ of the full models ranged from $34 \%$ to $42 \%$ for IGF-I, $19 \%$ to $20 \%$ for IGFBP-1, $17 \%$ to $18 \%$ for IGFBP-2, and $36 \%$ to $39 \%$ for IGFBP-3.

which we could not confirm in the current cross-sectional study. Several methodological aspects of our study may have contributed to this. The FFQ used for the assessment of phytoestrogens and related foods, and lycopene and tomato intake, was not specifically designed for this purpose. Although the FFQ contained most of the important food sources of phytoestrogens (tempeh, tofu, vegetarian burgers, and legumes) and lycopene (pasta sauce, raw tomatoes, baked/fried tomatoes), other food items that may have contributed to phytoestrogen and lycopene intake were not included in the questionnaire (e.g. soy milk, tomato soup). Therefore, the true intake of phytoestrogens and lycopene in our population may be underestimated. Overall, intake of phytoestrogens and lycopene in our study is relatively low, but comparable to that observed in many other Western populations [44, 58-60]. Within this low range, limited variation in phytoestrogens and related foods, and lycopene and tomato intake might explain why we did not observe an association with IGF-I and IGFBP-3. Additionally, much higher phytoestrogen and lycopene intakes may be needed to affect the IGF-system. However, it is also possible that phytoestrogens and lycopene mainly influence IGFBP-1 and IGFBP-2 levels, and do not have a direct effect on IGF-I and IGFBP-3, as is also suggested by our results.

Some general remarks can be made about the design of our study. The association between diet and the IGF-system might differ by gender, menopausal status, and menstrual cycle phase, as the IGFsystem is known to be strongly interrelated with estrogen action. Therefore, we studied pre- and postmenopausal women separately, although we were not able to adjust for menstrual cycle phase. As the premenopausal women in our study were relatively old, they may not be comparable to premenopausal women in general. However, our study is a good reflection of a Western population of women over 50 with respect to IGF levels $[4,7,8]$ and dietary intake. With respect to the relevant time frame, it is yet unknown which has the greatest effect on the IGFsystem: a high dietary exposure for a short duration or a relatively low dietary exposure for a longer duration, which is the type of exposure we assessed in the current study. Consequently, we do not know whether food intake in the days prior to plasma sampling may have disturbed any association between plasma IGF levels and habitual food intake as assessed by our questionnaire.

In conclusion, in the current study the two IGF binding proteins, IGFBP-1 and IGFBP-2, which have received relatively little attention in epidemiological studies so far, were associated with the consumption of alcohol and some measures of phytoestrogen intake. The relevance of changes in plasma concentrations of these binding proteins, also with respect to IGF-I bioactivity, remains controversial and deserves further investigation. Besides alcohol, we found no dietary determinants of IGF-I and IGFBP-3 in our study. It would be interesting to investigate these dietary factors in relation to the IGF-system in populations with a higher consumption and greater variation in consumption of phytoestrogens or lycopene (e.g. Asian or Italian populations). Human dietary intervention studies would 
ultimately provide the answers with respect to the effects of these dietary compounds on the different circulating IGF components.

\section{Acknowledgment}

The study was financially supported by the World Cancer Research Fund, WCRF, Grant No. 98-04.

\section{References}

1. Khandwala HM, McCutcheon IE, Flyvbjerg A, Friend KE (2000) The effects of insulin-like growth factors on tumorigenesis and neoplastic growth. Endocr Rev 21: 215-244.

2. Chan JM, Stampfer MJ, Giovannucci E, et al. (1998) Plasma insulin-like growth factor-I and prostate cancer risk: a prospective study. Science 279: 563-566.

3. Stattin P, Bylund A, Rinaldi S, et al. (2000) Plasma insulin-like growth factor-I, insulin-like growth factor-binding proteins, and prostate cancer risk: a prospective study. J Natl Cancer Inst $\mathbf{9 2}$ 1910-1917.

4. Hankinson SE, Willett WC, Colditz GA, et al. (1998) Circulating concentrations of insulin-like growth factor-I and risk of breast cancer. Lancet 351: 1393-1396.

5. Toniolo P, Bruning PF, Akhmedkhanov A, et al. (2000) Serum insulin-like growth factor-I and breast cancer. Int $J$ Cancer $\mathbf{8 8}$ 828-832.

6. Ma J, Pollak MN, Giovannucci E, et al. (1999) Prospective study of colorectal cancer risk in men and plasma levels of insulin-like growth factor (IGF)-1 and IGF-binding protein-3. J Natl Cancer Inst 91: 620-625.

7. Giovannucci E, Pollak MN, Platz EA, et al. (2000) A prospective study of plasma insulin-like growth factor-I and binding protein-3 and risk of colorectal neoplasia in women. Cancer Epidemiol Biomarkers Prev 9: 345-349.

8. Kaaks R, Toniolo P, Akhmedkhanov A, et al. (2000) Serum Cpeptide, insulin-like growth factor (IGF)-I, IGF-binding proteins, and colorectal cancer risk in women. J Natl Cancer Inst 92: 15921600 .

9. Collett-Solberg PF, Cohen P (2000) Genetics, chemistry, and function of the IGF/IGFBP system. Endocrine 12: 121-136.

10. Harrela M, Koistinen H, Kaprio J, et al. (1996) Genetic and environmental components of interindividual variation in circulating levels of IGF-I, IGF-II, IGFBP-1, and IGFBP-3. J Clin Invest 98: 2612-2615.

11. Thissen JP, Ketelslegers JM, Underwood LE (1994) Nutritional regulation of insulin-like growth factors. Endocr Rev 15: 80-101.

12. Darling-Raedeke M, Thornton WH, MacDonald RS (1998) Growth hormone and IGF-I plasma concentrations and macronutrient intake measured in a free-living elderly population during a one-year period. J Am Coll Nutr 17: 392-397.

13. Kaklamani VG, Linos A, Kaklamani E, Markaki I, Koumantaki Y, Mantzoros CS (1999) Dietary fat and carbohydrates are independently associated with circulating insulin-like growth factor 1 and insulin-like growth factor-binding protein 3 concentrations in healthy adults. J Clin Oncol 17: 3291-3298.

14. Mucci LA, Tamimi R, Lagiou P, et al. (2001) Are dietary influences on the risk of prostate cancer mediated through the insulin-like growth factor system? BJU Int 87: 814-820.
15. Signorello LB, Kuper H, Lagiou P, et al. (2000) Lifestyle factors and insulin-like growth factor 1 levels among elderly men. Eur $J$ Cancer Prev 9: 173-178.

16. Chang S, Wu X, Yu H, Spitz MR (2002) Plasma concentrations of insulin-like growth factors among healthy adult men and postmenopausal women: associations with body composition, lifestyle, and reproductive factors. Cancer Epidemiol Biomarkers Prev 11: 758-766.

17. Allen NE, Appleby PN, Davey GK, Kaaks R, Rinaldi S, Key TJ (2002) The associations of diet with serum insulin-like growth factor I and its main binding proteins in 292 women meat-eaters, vegetarians, and vegans. Cancer Epidemiol Biomarkers Prev 11: 1441-1448.

18. Gunnell D, Oliver SE, Peters TJ, et al. (2003) Are diet-prostate cancer associations mediated by the IGF axis? A cross-sectional analysis of diet, IGF-I and IGFBP-3 in healthy middle-aged men. Br J Cancer 88: 1682-1686.

19. Nagata C, Shimizu H, Takami R, Hayashi M, Takeda N, Yasuda K (2003) Dietary soy and fats in relation to serum insulin-like growth factor- 1 and insulin-like growth factor-binding protein-3 levels in premenopausal Japanese women. Nutr Cancer 45: 185-189.

20. Probst-Hensch NM, Wang H, Goh VH, Seow A, Lee HP, Yu MC (2003) Determinants of circulating insulin-like growth factor I and insulin-like growth factor binding protein 3 concentrations in a cohort of Singapore men and women. Cancer Epidemiol Biomarkers Prev 12: 739-746.

21. Devine A, Rosen C, Mohan S, Baylink D, Prince RL (1998) Effects of zinc and other nutritional factors on insulin-like growth factor I and insulin-like growth factor binding proteins in postmenopausal women. Am J Clin Nutr 68: 200-206.

22. Holmes MD, Pollak MN, Willett WC, Hankinson SE (2002) Dietary correlates of plasma insulin-like growth factor I and insulin-like growth factor binding protein 3 concentrations. Cancer Epidemiol Biomarkers Prev 11: 852-861.

23. Giovannucci E, Pollak M, Liu Y, et al. (2003) Nutritional predictors of insulin-like growth factor I and their relationships to cancer in men. Cancer Epidemiol Biomarkers Prev 12: 84-89.

24. Heald AH, Cade JE, Cruickshank JK, Anderson S, White A, Gibson JM (2003) The influence of dietary intake on the insulinlike growth factor (IGF) system across three ethnic groups: a population-based study. Public Health Nutr 6: 175-180.

25. Yu H (1998) Alcohol consumption and breast cancer risk. JAMA 280: $1138-1139$.

26. Goodman-Gruen D, Barrett-Connor E (1997) Epidemiology of insulin-like growth factor-I in elderly men and women: the Rancho Bernardo Study. Am J Epidemiol 145: 970-976.

27. Ho GH, Ji CY, Phang BH, Lee KO, Soo KC, Ng EH (1998) Tamoxifen alters levels of serum insulin-like growth factors and binding proteins in postmenopausal breast cancer patients: a prospective paired cohort study. Ann Surg Oncol 5: 361-367.

28. Bonanni B, Johansson H, Gandini S, et al. (2001) Effect of low dose tamoxifen on the insulin-like growth factor system in healthy women. Breast Cancer Res Treat 69: 21-27.

29. Torrisi R, Baglietto L, Johansson H, et al. (2001) Effect of raloxifene on IGF-I and IGFBP-3 in postmenopausal women with breast cancer. Br J Cancer 85: 1838-1841.

30. Setchell KD (2001) Soy isoflavones - benefits and risks from nature's selective estrogen receptor modulators (SERMs). $J \mathrm{Am}$ Coll Nutr 20: 354S-362S

31. Wangen KE, Duncan AM, Merz-Demlow BE, et al. (2000) Effects of soy isoflavones on markers of bone turnover in premenopausal and postmenopausal women. $J$ Clin Endocrinol Metab 85: 3043-3048 
32. Khalil DA, Lucas EA, Juma S, Smith BJ, Payton ME, Arjmandi BH (2002) Soy protein supplementation increases serum insulinlike growth factor- I in young and old men but does not affect markers of bone metabolism. J Nutr 132: 2605-2608.

33. Adams KF, Newton KM, Chen C, et al.(2003) Soy isoflavones do not modulate circulating insulin-like growth factor concentrations in an older population in an intervention trial. J Nutr 133: 1316-1319.

34. Levy J, Bosin E, Feldman B, et al. (1995) Lycopene is a more potent inhibitor of human cancer cell proliferation than either alpha-carotene or beta-carotene. Nutr Cancer 24: 257-266.

35. Karas M, Amir H, Fishman D, et al. (2000) Lycopene interferes with cell cycle progression and insulin-like growth factor I signaling in mammary cancer cells. Nutr Cancer 36: 101-111.

36. Liu C, Lian F, Smith DE, Russell RM, Wang XD (2003) Lycopene supplementation inhibits lung squamous metaplasia and induces apoptosis via up-regulating insulin-like growth factor-binding protein 3 in cigarette smoke-exposed ferrets. Cancer Res 63: 3138-3144.

37. Riboli E (1992) Nutrition and cancer: background and rationale of the European Prospective Investigation into Cancer and Nutrition (EPIC). Ann Oncol 10: 783-791.

38. Keinan-Boker L, van Noord PAH, van der Schouw YT, et al. (2001) Prospect-EPIC Utrecht: study design and characteristics of the cohort population. European Prospective Investigation into Cancer and Nutrition. Eur J Epidemiol 17: 1047-1053.

39. Voskuil DW, Bueno de Mesquita HB, Kaaks R, et al. (2001) Determinants of circulating insulin-like growth factor (IGF)-I and IGF binding proteins $1-3$ in pre-menopausal women: physical activity and anthropometry (Netherlands). Cancer Causes Control 12: 951-958.

40. Keinan-Boker L, Bueno de Mesquita HB, Kaaks R, et al. (2003) Circulating levels of insulin-like growth factor I, its binding proteins -1, -2, -3, C-peptide and risk of postmenopausal breast cancer. Int $J$ Cancer 106: 90-95.

41. Voorrips LE, Ravelli ACJ, Dongelmans PCA, Deurenberg P, van Staveren WA (1991) A physical activity questionnaire for the elderly. Med Sci Sports Exer 23: 974-979.

42. Ocké MC, Bueno de Mesquita HB, Goddijn HE, et al. (1997) The Dutch EPIC food frequency questionnaire. I. Description of the questionnaire, and relative validity and reproducibility for food groups. Int J Epidemiol 26(Suppl 1): S37-S48.

43. Ocké MC, Bueno de Mesquita HB, Pols MA, Smit HA, van Staveren WA, Kromhout D (1997) The Dutch EPIC food frequency questionnaire. II. Relative validity and reproducibility for nutrients. Int J Epidemiol 26(Suppl 1): S49-S58.

44. de Kleijn MJ, van der Schouw YT, Wilson PW, et al. (2001) Intake of dietary phytoestrogens is low in postmenopausal women in the United States: the Framingham study(1-4). J Nutr 131: 1826-1832.

45. Keinan-Boker L, van der Schouw YT, de Kleijn MJJ, Jacques PF, Grobbee DE, Peeters PHM (2002) Intake of dietary phytoestrogens by Dutch women. $J$ Nutr 132: 1319-1328.
46. Willett W, Stampfer MJ (1986) Total energy intake: implications for epidemiologic analyses. Am J Epidemiol 124: 17-27.

47. World Cancer Research Fund (1997) Food, Nutrition and the Prevention of Cancer: a Global Perspective. Washington, DC: American Institute for Cancer Research.

48. Kaaks R, Lukanova A (2001) Energy balance and cancer: the role of insulin and IGF-I. Proc Nutr Soc 60: 91-106.

49. Bagnardi V, Blangiardo M, La Vecchia C, Corrao G (2001) A metaanalysis of alcohol drinking and cancer risk. $B r J$ Cancer 85 : 1700-1705.

50. Hamajima N, Hirose K, Tajima K, et al. (2002) Alcohol, tobacco and breast cancer - collaborative reanalysis of individual data from 53 epidemiological studies, including 58,515 women with breast cancer and 95,067 women without the disease. $\mathrm{Br} J$ Cancer 87: 1234-1245.

51. Smith-Warner SA, Spiegelman D, Yaun SS, et al. (1998) Alcohol and breast cancer in women: a pooled analysis of cohort studies. JAMA 279: 535-540.

52. Zhou JR, Gugger ET, Tanaka T, Guo Y, Blackburn GL, Clinton SK (1999) Soybean phytochemicals inhibit the growth of transplantable human prostate carcinoma and tumor angiogenesis in mice. J Nutr 129: 1628-1635.

53. Lamartiniere CA, Cotroneo MS, Fritz WA, Wang J, MentorMarcel R, Elgavish A (2002) Genistein chemoprevention: timing and mechanisms of action in murine mammary and prostate. J Nutr 132: 552S-558S

54. Chen J, Stavro PM, Thompson LU (2002) Dietary flaxseed inhibits human breast cancer growth and metastasis and downregulates expression of insulin-like growth factor and epidermal growth factor receptor. Nutr Cancer 43: 187-192.

55. Arjmandi BH, Khalil DA, Smith BJ, et al. (2003) Soy protein has a greater effect on bone in postmenopausal women not on hormone replacement therapy, as evidenced by reducing bone resorption and urinary calcium excretion. J Clin Endocrinol Metab 88: 1048-1054.

56. Giovannucci E (1999) Tomatoes, tomato-based products, lycopene, and cancer: review of the epidemiologic literature [see comments]. J Natl Cancer Inst 91: 317-331.

57. Kucuk O, Sarkar FH, Sakr W, et al. (2001) Phase II randomized clinical trial of lycopene supplementation before radical prostatectomy. Cancer Epidemiol Biomarkers Prev 10: 861-868.

58. Horn-Ross PL, Lee M, John EM, Koo J (2000) Sources of phytoestrogen exposure among non-Asian women in California, USA. Cancer Causes Control 11: 299-302.

59. Goldbohm RA, Brants HA, Hulshof KF, van den Brandt PA (1998) The contribution of various foods to intake of vitamin A and carotenoids in The Netherlands. Int $J$ Vitam Nutr Res 68 : 378-383.

60. O’Neill ME, Carroll Y, Corridan B, et al. (2001) A European carotenoid database to assess carotenoid intakes and its use in a five-country comparative study. Br J Nutr 85: 499-507. 